\title{
IDENTIFICATION OF DROUGHT-TOLERANT WOODY PERENNIALS USING CHLOROPHYLL FLUORESCENCE
}

\author{
by Glynn C. Percival' ${ }^{1}$ and Colin N. Sheriffs ${ }^{2}$
}

\begin{abstract}
The purpose of this research was to determine whether chlorophyll fluorescence values obtained from excised leaves of woody plants subjected to dehydration in vitro provided a measurable indicator of whole-plant performance following drought in situ and to gain a greater understanding of alterations in leaf photosynthetic properties between species. Based on reductions in photochemical efficiency, as measured by chlorophyll fluorescence, of detached leaves of 30 woody plants in vitro following 24 hours of dehydration, plants were ranked in order of tolerance. Five species identified as drought tolerant, intermediate, and sensitive were subjected to 70 days of drought under glasshouse conditions. Based on mortality rates at day 70 , drought tolerance followed the same order as that obtained in vitro. In addition, reductions in chlorophyll fluorescence parameters and photosynthetic rates of whole plants mirrored tolerance ranking in vitro (i.e., rates declined most rapidly in species identified as dehydration sensitive and least in species identified as drought tolerant). Alteration to leaf chlorophyll fluorescence parameters in the test species highlighted a number of previously unreported effects on the leaf photosynthetic apparatus in response to drought. Results strongly indicate that screening of detached leaf material in vitro using chlorophyll fluorescence can provide a means of gauging the drought tolerance of plants with limited whole-plant experimentation.
\end{abstract}

Key Words. Photosynthesis; carbon allocation; woody plants, drought resistance; dehydration tolerance.

It is now widely recognized that urban landscapes create an environment that is hostile to tree growth. Trees have to contend with problems such as soil compaction, waterlogging, drought and de-icing salts. The consequences can be short-lived planting schemes, as hundreds of thousands of plants degenerate and die annually in the United Kingdom (Gilbertson and Bradshaw 1985; Craul 1994; Gibbs and Palmer 1994). In areas where newly planted trees are not irrigated, initial establishment relies heavily on precipitation. If the transplant does not receive water during the period of new root regeneration, its internal water deficits increase considerably due to excessive water transpiration and nonabsorption of water from soil (Kozlowski et al. 1991). Indeed, water deficits are the major causes of failure of newly planted trees (Kaushal and Aussenac 1989). Because trees planted in urban landscapes are selected primarily on their aesthetic qualities, little information exists concerning their drought tolerance. Determining the drought tolerance of woody plants, however, can be expensive, requiring time-consuming and labor-intensive glasshouse, street trials, and/or field trials. A rapid and accurate method to identify drought-tolerant woody plants for future urban plantings is now required.

A promising approach is the use of chlorophyll fluorescence, a technique that can provide large amounts of data with a minimum of expertise and time and without injury to the plants. Chlorophyll fluorescence works on the principle that photosynthesis is one of the core functions in the physiology of plants. The functional state of photosynthesis has been considered an ideal physiological activity to monitor the health and vitality of plants (Clark et al. 2000). Assessing the health or integrity of the internal apparatus driving the photosynthetic process within a leaf (i.e., the thylakoid membrane) using chlorophyll fluorescence provides a rapid and accurate technique of detecting and quantifying plant tolerance to stress. Furthermore, previous research indicates that chlorophyll fluorescence values from detached leaves strongly correlate with wholeplant mortality in response to environmental stress (freezing, heat, chilling, salinity), permitting quantification of species and cultivar tolerance with limited whole-plant experimentation (Smillie and Hetherington 1983; Greaves and Wilson 1987; Brennan and Jefferies 1990; Yamada et al. 1996; Hakam et al. 2000).

Objectives of this investigation were to (1) determine whether chlorophyll fluorescence values obtained from excised leaves of urban woody perennials subject to dehydration in vitro provide a measurable indicator of whole-plant performance under drought conditions in situ and (2) gain a greater understanding 
of alterations in leaf photosynthetic properties and other key physiological traits between species in response to drought.

\section{MATERIALS AND METHODS Plant Material}

The experiment used 4-year-old stock of a range of woody perennials commonly used in United Kingdom planting schemes obtained from a range of commercial suppliers. At each sampling, shoots consisting of current year's growth were collected from each species and placed in paper bags for transport to the laboratory. Five fully expanded, nonsenescing leaves per shoot were excised from the base of the petiole using a razor blade; all material was prepared within 2 hours of collection. Samples were collected in late June-well beyond the initial 21 days required after leaf flush (circa early May) - to allow the photosynthetic apparatus to fully develop (Kitao et al. 1998).

\section{Treatments}

In Vitro. Immediately following detachment, leaves were dehydrated in vitro by placing abaxial surface down, in a uncovered Petri dish on Watman filter paper and placed in a Merck environmental growth chamber at $21^{\circ} \mathrm{C}\left(70^{\circ} \mathrm{F}\right)$ for 24 hours at a $35 \%$ relative humidity and low light intensity of $15 \mu \mathrm{mol} \mathrm{m} \mathrm{m}^{-2} \mathrm{~s}^{-1}$ photosynthetically active radiation (PAR) to induce stomatal opening and facilitate maximal water loss from leaf tissue (Jensen et al. 1999). The influence of leaf detachment was determined by placing detached leaves, abaxial surface down, in a Petri dish on moist Watman filter paper sealed with a thin polythene film permeable to air but not water.

Whole plants. Four-year-old stock of five woody perennials identified in vitro as dehydration tolerant (Aucuba japonica 'Variegata', Prunus laurocerasus 'Zabeliana'), intermediate (Pieris 'Forest Flame'), and sensitive (Euonymous fortunei 'Emerald 'n' Gold' and Spiraea japonica 'Shirobana') were placed under glasshouse conditions at a temperature of $22^{\circ} \mathrm{C}\left(72^{\circ} \mathrm{F}\right) \pm 2^{\circ} \mathrm{C}\left(36^{\circ} \mathrm{F}\right)$ supplemented with 400-W, high-pressure sodium lamps (SON/T) providing a photoperiod of 16 hours light and 8 hours dark and $250 \mu \mathrm{mol} \mathrm{m} \mathrm{m}^{-2} \mathrm{~s}^{-1}$ PAR at the tree crown and allowed to grow for 1 month. After 1 month, plants were watered until the compost (loamy texture, with $23 \%$ clay, $46 \%$ silt, $31 \%$ sand, $3.1 \%$ organic carbon, $\mathrm{pH}$ 6.6) was fully saturated (i.e., water was observed emerging from drainage holes). Immediately thereaf- ter, drought treatments were imposed by the cessation of watering. The experimental design used was a completely randomized block that was continually randomized on a weekly basis. Experiments were undertaken in May 1999 using eight plants per treatment and repeated in May 2001 using six plants per treatment.

Chlorophyll fluorescence. Leaves were adapted to darkness for 30 minutes by attaching light-exclusion clips to the leaf surface in situ. Chlorophyll fluorescence was measured using a portable fluorescence spectrometer (Hansatech Instruments Ltd., Kings Lynn, U.K.). Measurements were recorded up to 1 second with a data acquisition rate of $10 \mathrm{~ms}$ for the first $2 \mathrm{~ms}$ and of $1 \mathrm{~ms}$ thereafter. The fluorescence responses were induced by a red (peak at $650 \mathrm{~nm}$ ) light of $600 \mathrm{~W} \mathrm{~m}^{-2}$ intensity provided by an array of six light-emitting diodes. Fluorescence values recorded include

Fo: Minimal fluorescence. Increased or decreased values indicate damage or impairment of the photosynthetic apparatus.

Fv/Fo: Estimates the maximum primary yield of photochemistry of photoystem II and provides an estimation of photosynthetic capacity.

Fv/Fm: Represents the maximum quantum yield of photoystem II, which in turn is highly correlated with the quantum yield of net photosynthesis.

Dehydration tolerance in vitro was assessed by reductions in $\mathrm{Fv} / \mathrm{Fm}$ values only because $\mathrm{Fv} / \mathrm{Fm}$ values are the most popular index used as a measure of plant vitality and early diagnostic of stress in situ (Meinander et al. 1996).

\section{Photosynthetic $\mathrm{CO}_{\mathbf{2}}$ Fixation}

The light-induced $\mathrm{CO}_{2}$ fixation (Pn) was measured in pre-darkened leaves $(20$ minutes $)$ using a $\mathrm{CO}_{2} / \mathrm{H}_{2} \mathrm{O}$ porometer (Walz D-91090 Effeltrich). The irradiance on the leaves was $700 \mu \mathrm{mol} \mathrm{m}{ }^{-2} \mathrm{~s}^{-1}$ PAR saturating with respect to Pn; the velocity of the airflow was $0.5 \mathrm{~L} \mathrm{~min}^{-1}$. The calculation of the photosynthetic rates was carried out according to von Caemmerer and Farquhar (1981).

\section{Plant Dry Weights}

At the conclusion of the experiment, surviving trees were destructively harvested and leaf, shoot, and root dry weight recorded after oven drying at $85^{\circ} \mathrm{C}\left(185^{\circ} \mathrm{F}\right)$ for 48 hours. 


\section{Statistical Analysis}

Multivariate analysis was used to determine the significance of species and dehydration on chlorophyll fluorescence and photosynthetic rates using the Genstat V version 3.1 program. Because a significant effect of dehydration was recorded, the program was restricted to analyze for treatment effects within each species. Differences between treatment means were separated by the least significance difference (LSD) at $P>0.05$. Photosynthetic $\mathrm{CO}_{2}$ fixation was measured in the May 1999 experiment only. In no instances did treatment effects on chlorophyll fluorescence values of each species differ between years. Consequently, values represent pooled data for both years.

\section{RESULTS}

\section{In Vitro}

Values of detached leaves protected from the dehydration stress by sealing in Petri dishes on moist filter paper did not significantly differ from values recorded on whole plants (Table 1), demonstrating no significant effect of leaf detachment on photochemical efficiency $(\mathrm{Fv} / \mathrm{Fm})$. Likewise, no significant intra-specific differences in $\mathrm{Fv} / \mathrm{Fm}$ values between the 30 species selected for experimental purposes were recorded. $\mathrm{Fv} / \mathrm{Fm}$ values of all species ranged between 0.804 and 0.818 . For reasons of clarity, only results for ten species are shown (Table 1). A significant effect of species in response to dehydration was recorded. This finding is reflected by marked differences in the magnitude of the stress response recorded between species (Table 2). In all cases, dehydration reduced $\mathrm{Fv} / \mathrm{Fm}$ values.

Table 1. The effect of leaf detachment on photochemical efficiency (Fv/Fm) of woody plants tested.

\begin{tabular}{lll}
\hline & \multicolumn{2}{c}{ Fv/Fm } \\
\cline { 2 - 3 } Species & Whole plant & Detached leaf \\
\hline Aucuba japonica 'Variegata' & $0.810^{\mathrm{ns}}$ & $0.809^{\mathrm{ns}}$ \\
Pinus sylvestris & $0.807^{\mathrm{ns}}$ & $0.808^{\mathrm{ns}}$ \\
Mahonia $\times$ media 'Charity' & $0.811^{\mathrm{ns}}$ & $0.807^{\mathrm{ns}}$ \\
Prunus laurocerasus 'Zabeliana' & $0.809^{\mathrm{ns}}$ & $0.811^{\mathrm{ns}}$ \\
Weigela florida & $0.813^{\mathrm{ns}}$ & $0.814^{\mathrm{ns}}$ \\
Pieris 'Forest Flame' & $0.810^{\mathrm{ns}}$ & $0.807^{\mathrm{ns}}$ \\
Ilex aquifolium & $0.815^{\mathrm{ns}}$ & $0.818^{\mathrm{ns}}$ \\
Euonymus fortunei 'Emerald 'n' Gold' & $0.812^{\mathrm{ns}}$ & $0.811^{\mathrm{ns}}$ \\
Juglans regia & $0.804^{\mathrm{ns}}$ & $0.808^{\mathrm{ns}}$ \\
Salix daphnoides & $0.810^{\mathrm{ns}}$ & $0.806^{\mathrm{ns}}$ \\
LSD P $<0.05$ & \multicolumn{2}{c}{0.075} \\
LSD P $<0.01$ & \multicolumn{2}{c}{0.043} \\
\hline
\end{tabular}

Species $=$ ns, leaf detachment $=$ ns, species $\times$ leaf detachment $=$ ns. All values mean of 10 plants; 10 leaves per plant. $\mathrm{ns}=$ not significant.
Consequently, species were ranked in order of drought tolerance based on reductions in $\mathrm{Fv} / \mathrm{Fm}$ values after 24 hours of dehydration. Based on $\mathrm{Fv} / \mathrm{Fm}$ ranking in vitro, five species were identified as drought tolerant (Aucuba japonica 'Variegata', Prunus laurocerasus 'Zabeliana'), intermediate (Pieris 'Forest Flame'), sensitive (Euonymus fortunei 'Emerald 'n' Gold'), and very sensitive (Spiraea japonica 'Shirobana') and used for whole-plant experimentation.

\section{Whole Plants}

Effects on photochemical efficiency and photosynthetic capacity (Fv/Fm and $\mathrm{Fv} / \mathrm{Fo}$ values, respectively) followed similar trends for all species in that reduc-

Table 2. The influence of 24-hour dehydration on photochemical efficiency (Fv/Fm) of detached leaves of woody plants.

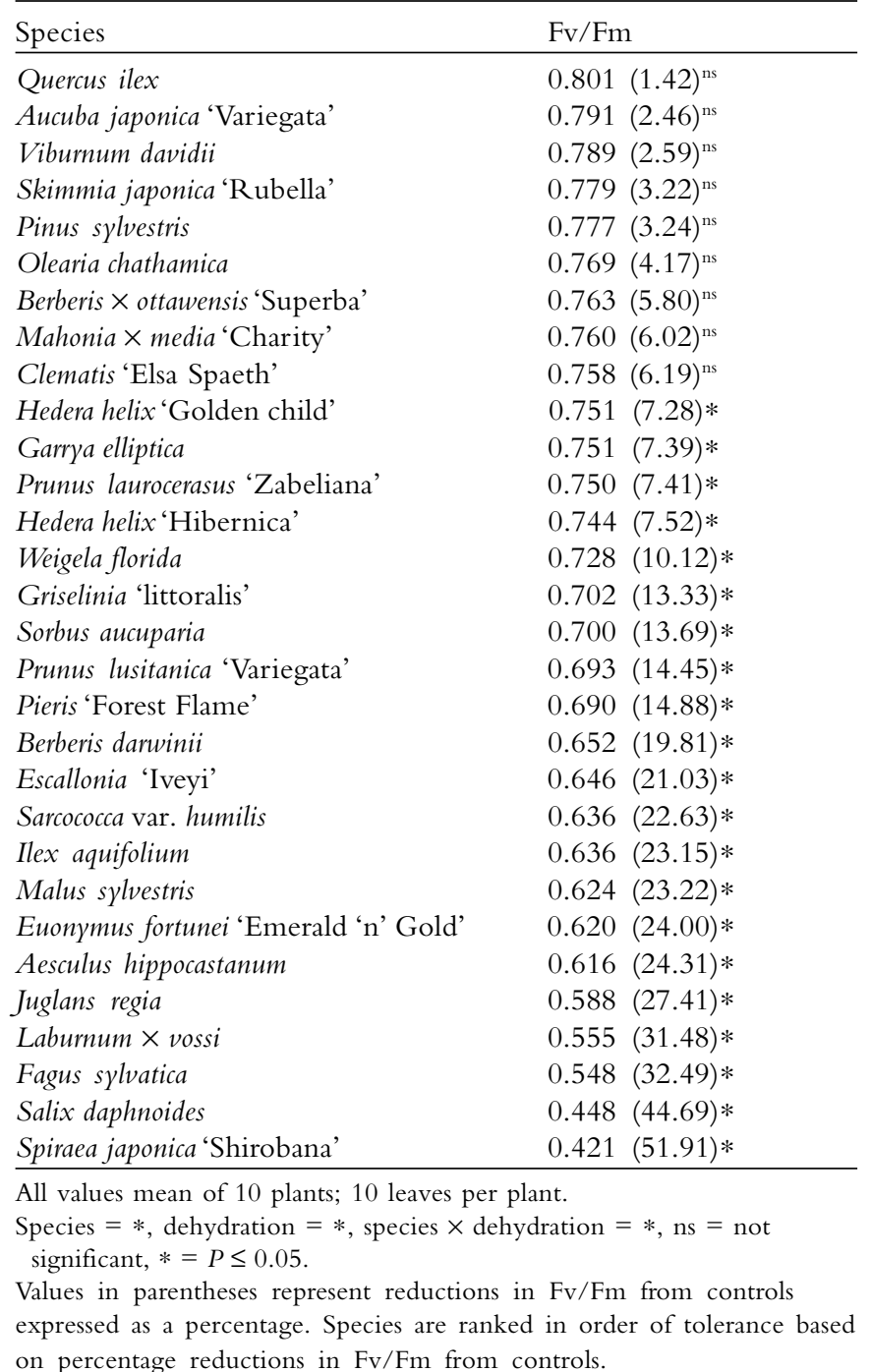


tions with time following cessation of watering were recorded (Figure 1). Effects on Pieris 'Forest Flame', Euonymus fortunei 'Emerald 'n' Gold', and Spiraea japonica 'Shirobana' were recorded by week 1 but not until weeks 3 and 4 in the case of Aucuba japonica 'Variegata' and Prunus laurocerasus 'Zabeliana'. Effects on Fo as a measure of damage to the photosynthetic apparatus differed between species. In the cases of Pieris 'Forest Flame', Euonymus fortunei 'Emerald 'n' Gold', and Spiraea japonica 'Shirobana', Fo values steadily declined from day 0 until the termination of the experiment (day 70). In the cases of Aucuba japonica 'Variegata' and Prunus laurocerasus 'Zabeliana', Fo values increased until week 1 and then steadily
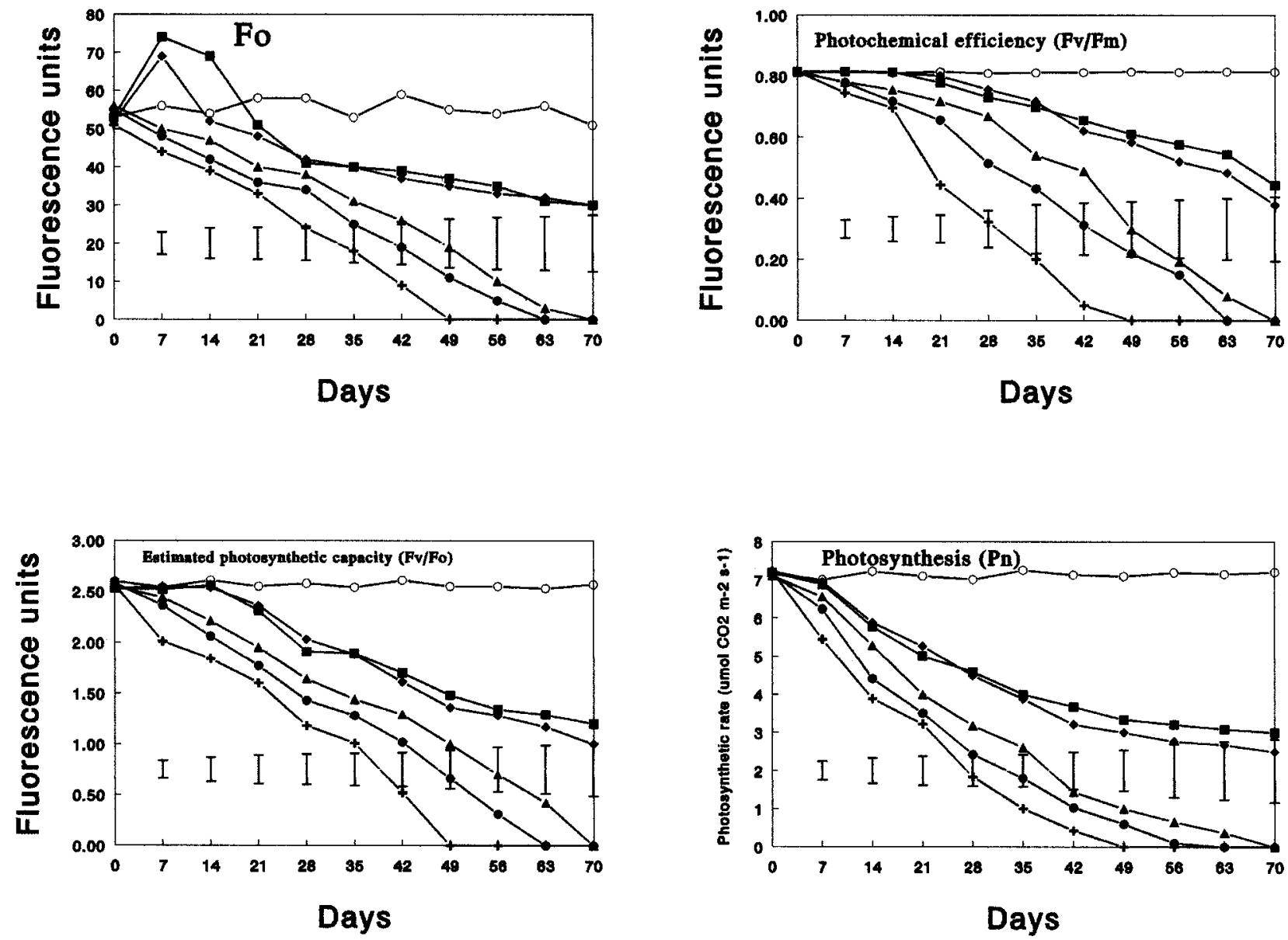

Figure 1. The influence of drought on chlorophyll fluorescence and photosynthetic rate of five woody perennials with time.

$\mathbf{O}=$ Aucuba japonica 'Variegata' (control)

$+=$ Spiraea japonica 'Shirobana'

$\bullet=$ Euonymus fortunei 'Emerald 'n' Gold'

$\Delta=$ Pieris 'Forest Flame'

$\diamond=$ Prunus laurocerasus 'Zabeliana'

= Aucuba japonica 'Variegata'

All values mean of 14 plants; 5 leaves per plant except $P n(n=8)$.

Error bars represent the least significant difference $(P=0.05)$ between treatments. 
declined until day 70. For all species, photosynthetic rates declined following the initiation of drought stress, although the rate of decline varied markedly between species.

\section{Growth and Mortality}

Based on mortality rates after the 10-week drought treatment, species tolerance was in the order Aucuba japonica 'Variegata' $>$ Prunus laurocerasus 'Zabeliana' > Pieris 'Forest Flame' > Euonymus fortunei 'Emerald 'n' Gold' > Spiraea japonica 'Shirobana' (35\%, 40\%, 75\%, $95 \%$, and $100 \%$ mortality, respectively). Time to wilting varied markedly between species. The earliest symptoms were observed visually in Spiraea japonica 'Shirobana', identified as the most drought-sensitive species in vitro at day 9. Wilting was not observed until day 48 in Aucuba japonica 'Variegata', identified as the most drought-tolerant species in vitro. Leaf drop was recorded after 21, 36, and 45 days for Spiraea japonica 'Shirobana', Euonymus fortunei 'Emerald 'n' Gold', and Pieris 'Forest Flame', respectively. No leaf drop was recorded in the species Aucuba japonica 'Variegata' and Prunus laurocerasus 'Zabeliana'. Irrespective of species, drought stress significantly reduced $(P>0.05)$ leaf, shoot, and root dry weight of all species tested by week 10 (Table 3), with one exception: shoot dry weight of Prunus laurocerasus 'Zabeliana', which did not significantly differ from controls.

\section{DISCUSSION}

According to Ludlow (1989), perhaps the single most important determinant of drought resistance within a plant is the dehydration tolerance (i.e., the measure of tissue capacity for withstanding desiccation). Based on reductions in photochemical efficiency as measured by $\mathrm{Fv} / \mathrm{Fm}$ ratios of detached leaves after 24 hours of dehydration, the dehydration tolerance of five of the 30 plants tested was in the order Aucuba japonica 'Variegata' > Prunus laurocerasus 'Zabeliana' > Pieris 'Forest Flame' > Euonymus fortunei 'Emerald 'n' Gold' > Spiraea japonica 'Shirobana'. Based on whole-plant mortality after 70 days of drought, tolerance followed the same order as that obtained in vitro. Likewise, reductions in chlorophyll fluorescence parameters and photosynthetic rates of whole plants mirrored tolerance ranking in vitro (i.e., rates declined most rapidly in Spiraea japonica 'Shirobana', identified as drought sensitive, and least in Aucuba japonica 'Variegata', identified as the most drought-tolerant species). Techniques that help toward the rapid, objective testing of woody plant species have been advocated as necessary to facilitate the selection of robust trees and shrubs that will survive into maturity, reducing replacement costs and giving permanence to the landscape (Patch 1994; Cregg 1995). Results of this investigation indicate screening of detached leaf material in vitro using chlorophyll fluorescence can provide a rapid means of gauging the drought tolerance of plants with limited whole-plant experimentation. Previous work elsewhere supports this hypothesis. Greaves and Wilson (1987) were among the first to demonstrate that chlorophyll fluorescence was able to distinguish between degrees of freezing tolerance among wild and cultivated potato and rice genotypes and in turn quantify their freezing sensitivity when leaf tissue was subjected in vitro to a $-5^{\circ} \mathrm{C}$ $\left(23^{\circ} \mathrm{F}\right)$ freezing regime. Evaluation of chlorophyll

Table 3. The influence of 70 days' drought on growth and mortality of five woody plant species.

\begin{tabular}{|c|c|c|c|c|c|c|c|c|c|}
\hline \multirow[b]{2}{*}{ Species } & \multicolumn{2}{|c|}{ Leaf dry weight (g) } & \multicolumn{2}{|c|}{ Shoot dry weight (g) } & \multicolumn{2}{|c|}{ Root dry weight (g) } & \multirow{2}{*}{$\begin{array}{l}\text { Time to } \\
\text { wilting } \\
\text { (days) }\end{array}$} & \multirow{2}{*}{$\begin{array}{l}\text { Time to } \\
\text { leaf drop } \\
\text { (days) }\end{array}$} & \multirow{2}{*}{$\begin{array}{l}\text { Mortality } \\
(\%)\end{array}$} \\
\hline & Control & Drought & Control & Drought & Control & Drought & & & \\
\hline Aucuba japonica 'Variegata' & 13.85 & $9.51 *$ & 4.63 & $3.14 *$ & 24.2 & $16.3 *$ & 48 & - & 35 \\
\hline LSD & \multicolumn{2}{|c|}{3.32} & \multicolumn{2}{|c|}{1.28} & \multicolumn{2}{|c|}{6.22} & & & \\
\hline Prunus laurocerasus 'Zabeliana' & 12.58 & $9.00 *$ & 7.72 & $6.72^{\mathrm{ns}}$ & 32.7 & $21.1 *$ & 45 & - & 40 \\
\hline LSD & \multicolumn{2}{|c|}{3.22} & \multicolumn{2}{|c|}{2.21} & \multicolumn{2}{|c|}{7.15} & & & \\
\hline Euonymus fortunei 'Emerald 'n' Gold' & 10.35 & $2.07 *$ & 12.64 & $8.60 *$ & 8.53 & $3.28 *$ & 25 & 36 & 95 \\
\hline LSD & \multicolumn{2}{|c|}{1.67} & \multicolumn{2}{|c|}{2.41} & \multicolumn{2}{|c|}{1.63} & & & \\
\hline Spiraea japonica 'Shirobana' & 6.63 & $0.00 *$ & 17.78 & $10.79 *$ & 10.12 & $4.41 *$ & 9 & 21 & 100 \\
\hline LSD & \multicolumn{2}{|c|}{1.07} & \multicolumn{2}{|c|}{3.13} & \multicolumn{2}{|c|}{2.88} & & & \\
\hline
\end{tabular}

All values mean of 10 plants.

Species $=*$, drought $=*$, species $\times$ drought $=*$, ns $=$ not significant, $*=P \leq 0.05 ;$ LSD $=$ least significant difference.

$-=$ no symptoms observed. In all cases, no wilting or leaf drop occurred in control plants. 
fluorescence as a means of screening different genotypes of black currant of known hardiness to spring frosts using detached leaf material provided a rapid screening technique for assessing frost hardiness (Brennan and Jefferies 1990). Further evidence is supplied by Smillie and Hetherington (1983) using leaf material of bean, cucumber, cabbage, mandarin, grapefruit, and lime subject to freezing and chilling damage, while research in Japan by Yamada et al. (1996) successfully used chlorophyll fluorescence to quantify the heat tolerance of a range of fruit crops based on detached leaf experiments. Finally, work by Hakam et al. (2000) concluded that measurement of chlorophyll fluorescence might provide a rapid method to pre-screen rose genotypes for chilling susceptibility.

Water stress after planting is generally recognized as the major factor in the United Kingdom resulting in death of newly transplanted trees (Gilbertson and Bradshaw 1985). Owing to the limited root system moved with a tree following transplanting, inability of a plant to establish appropriate mechanisms for water harvesting and/or conservation plus, in many instances, the soil's inability to store adequate water, physiological drought can be experienced even when climatic drought is not severe (Kendle 1995). Although the significance of drought stress on woody plant performance is broadly appreciated by professionals involved in tree use and management, when it becomes necessary to make decisions on plant selection for a given site, it is soon apparent that "hard" data on stress tolerance is poorly developed or nonexistent (Flint 1985; Hitchmough 1995; Percival and Hitchmough 1995). In such circumstances, many woody plants are selected for use on the basis of their aesthetic characteristics. Consequently, if, for example, Spiraea japonica 'Shirobana' was selected for wide-scale planting into a sandy soil prone to drought throughout the spring and summer, then results of this experiment indicate that by the following growing season, mortality rates could be as high as $100 \%$. This net effect is undesirable when it occurs on a metropolitan or regional scale. Alternatively, selection of Aucuba japonica 'Variegata' or Prunus laurocerasus 'Zabeliana' could result in mortality rates between $35 \%$ and $40 \%$, which would reduce labor and replacement costs. Such a result demonstrates how appropriate species and site selection can mean the difference between low and substantial plant mortality and emphasizes the need for further research to select woody plants with superior stress tolerance linked to desirable aesthetic characteristics. Survivability following planting will become of greater importance because future resource allocations to urban tree management are likely to decline, increasing pressure to deliver superior services at less costs.

Measurements of chlorophyll fluorescence in this experiment highlighted a number of previously unreported effects on the leaf photosynthetic apparatus between the species tested in response to drought. Functionally chlorophyll molecules within the leaf act in groups. Contained within that group are special pairs of chlorophyll a molecules, which promote electron transfer, known as reaction centers. The reaction center within photosystem II responsible for the water splitting and oxygen-evolving reaction of photosynthesis is known as P680 (Hall and Rao 1999). An increase in Fo, as demonstrated by Aucuba japonica 'Variegata' or Prunus laurocerasus 'Zabeliana', is associated with dissociation of the light-harvesting chlorophyll $a / b$ complexes from the P680 complex of photosystem II (Yamane et al. 2000). A decrease in Fo, as in the case of Pieris 'Forest Flame', Euonymus fortunei 'Emerald 'n' Gold', and Spiraea japonica 'Shirobana', has been suggested to reflect damage to regulatory processes external to P680, such as impairment of the photo-protective process that facilitates the dissipation of excess energy within the leaf (i.e., the xanthophyll cycle (Angelopoulous et al. 1996; Hong and $\mathrm{Xu}$ 1999).

In response to drought, often one of the most sensitive indicators of a plant's overall physiological state is stomatal behaviour (Croker et al. 1998). Stomatal closure permits the plant to balance water loss with carbon update, in turn improving long-term water-use efficiency and survival. Although not recorded in this investigation, reduced carbon uptake caused by stomatal closure would account for reductions in the rate of photosynthesis recorded in all species tested by day 7, while reductions in $\mathrm{Fv} / \mathrm{Fm}$ (photochemical efficiency) and $\mathrm{Fv} / \mathrm{Fo}$ (photosynthetic capacity) were not detected until week 3. Alterations in Fo, although differing among species, were detected by week 1 . Consequently, results of this investigation indicate direct measurements of photosynthetic rate or alterations to Fo values provided are more effective indicators of drought stress than are $\mathrm{Fv} / \mathrm{Fm}$ and $\mathrm{Fv} / \mathrm{Fo}$.

Stress detection in urban trees relies heavily on visual observations of, for example, leaf yellowing, 
crown dieback, etc. Such indicators can be subjective because they are based on human knowledge and interpretation, which can differ between individuals. Consequently, health evaluations can differ markedly between assessors. The first visible signs of drought stress in this investigation were manifested by leaf wilting. Time taken for wilting ranged from 9 to 48 days, depending on species. In all cases, effects on chlorophyll fluorescence were detected prior to visible signs of wilting. The implications of chlorophyll fluorescence as a stress detection system for use in urban forestry programs have been discussed elsewhere (Percival and Dixon 1997; Percival et al. 1998; Percival and Fraser 2001).

Results of this investigation support previous work in that chlorophyll fluorescence permits early detection of stress before physical signs of deterioration become evident, which allows remedial action prior to the tree becoming a public hazard.

\section{LITERATURE CITED}

Angelopoulous, K., B. Dichio, and C. Xiloyannis. 1996. Inhibition of photosynthesis in olive trees (Olea europea L.) during water stress and rewatering. J. Exp. Bot. 47(301):1093-1100.

Brennan, R.M., and R.A. Jefferies. 1990. The use of chlorophyll fluorescence in assessment of lowtemperature hardiness in blackcurrant (Ribes nigrum L.). Ann. App. Biol. 117:667-672

Clark, A.J., W. Landolt, J.B. Bucher, and R.J. Strasser. 2000. Beech (Fagus sylvatica) response to ozone exposure assessed with a chlorophyll $a$ fuorescence performance index. Env. Pollut. 109:501-507.

Craul, P.J. 1994. Soil compaction on heavily used sites. J. Arboric. 20(2):69-74.

Cregg, B.M. 1995. Plant moisture stress of green ash trees in contrasing urban sites. J. Arboric. 21(6):271-276.

Croker J.L., W.T. Willard, and R. Auge. 1998. Stomatal sensitivity of six temperate, deciduous tree species to non-hydraulic root-to-shoot signalling of partial soil drying. J. Exp. Bot. 49(321):761-774.

Flint, H.L. 1985. Plants showing tolerance of urban stress. J. Environ. Hortic. 3(2):85-89.

Gibbs, J.N., and C.A. Palmer. 1994. A survey of damage to roadside trees in London caused by the application of deicing salt during the 1990/91 winter. Arboric. J. 18(3):321343

Gilbertson, P., and A.D. Bradshaw. 1985. Tree survival in cities: The extent and nature of the problem. Arboric. J. 9:131142.

Greaves, J.A., and J.M. Wilson. 1987. Chlorophyll fluorescence analysis-An aid to plant breeders. Biologist 34(4):209-214.
Hakam, P., S. Khanizadeh, J.R. DeEll, and C. Richer. 2000. Assessing chilling tolerance in roses using chlorophyll fluorescence. Hortscience 35(2):184-186.

Hall D.O., and K.K. Rao. 1999. Photosynthesis (6th ed.). Cambridge University Press, Cambridge, U.K.

Hitchmough, J. 1995. Where are the new plants to come from? Harnessing nature and science, pp. 21-30. In Plants for Landscape Sites, Institute of Horticulture Conference.

Hong, S.S., and D.Q. Xu. 1999. Light-induced increase in chlorophyll fluorescence Fo level and the reversible inactivation of PSII reaction centers in soybean leaves. Photosyn. Res. 61:269-280.

Jensen, M., S. Chakir, and G.B. Feige. 1999. Osmotic and atmospheric dehydration effects in the lichens Hypogymnia physodes, Lobaria pulmonaria. and Peltigera aphthosa: An in vivo study of the chlorophyll fluorescence induction. Photosynthetica 37:393-404.

Kaushal, P., and G. Aussenac. 1989. Transplant shock in Corsican pine and cedar atlas seedlings: Internal water deficits, growth and root regeneration. For. Ecol. Manage. 27:29-40.

Kendle, T. 1995. The nature of soils on landscape sites and the effects on plants, pp 11-20. In Plants for Landscape Sites, Institute of Horticulture Conference.

Kitao, M., T.T. Lei, and T. Koike. 1998. Application of chlorophyll fluorescence to evaluate $\mathrm{Mn}$ tolerance of deciduous broad-leaved tree seedlings native to northern Japan. Tree Physiol. 18:135-140.

Kozlowski, T.T., P.J. Kramer, and S.G. Pallardy. 1991. The Physiological Ecology of Woody Plants. Academic Press, San Diego, CA.

Ludlow, M.M. 1989 Strategies in response to water stress, pp 269-281. In Kreeb, H.K., H. Richter, and T.M Hinckley (Eds.). Structural and Functional Responses to Environmental Stresses: Water Shortage. SPB Academic Press, The Hague, Netherlands.

Meinander, O., S. Somersalo, T. Holopainen, and R.J. Strasser. 1996. Scots pine after exposure to elevated ozone and carbon dioxide probed by reflectance spectra and chlorophyll a fluorescence transients. J. Plant Physiol. 148:229-236.

Patch, D. 1994. Management of trees and the environs in which they grow. Scott. For. 48(2):96-101.

Percival, G.C., and G.R. Dixon. 1997. Detection of salt and waterlogging stress in Alnus cordata by measurement of leaf chlorophyll fluorescence. J. Arboric. 23(5):181-190.

Percival, G C., and G.A. Fraser. 2001. Measurement of the salinity and freezing tolerance of Crataegus genotypes using chlorophyll fluorescence. J. Arboric. 27(5):233-245.

Percival, G.C., and J. Hitchmough 1995. Tree establishment and performance in a cool growing season arboretum. Arboric. J. 19(4):357-371. 
Percival, G.C., M. Biggs, and G.R. Dixon. 1998. The influence of sodium chloride and waterlogging stress on Alnus cordata. J. Arboric. 24:19-27.

Smillie, R.M., and S.E. Hetherington. 1983. Stress tolerance and stress-induced injury in crop plants measured by chlorophyll fluorescence in vivo. Plant Physiol. 72:1043-1050.

von Caemmerer, S., and G.D. Farquhar. 1981. Some relationships between the biochemistry of photosynthesis and the gas exchange of leaves. Planta 153: 376-387.

Yamada, M., T. Hidaka, and H. Fukamachi. 1996. Heat tolerance in leaves of tropical fruit crops as measured by chlorophyll fluorescence. Sci. Hortic. 67:39-48.

Yamane, Y., T. Shikanai, Y. Kashino, H. Koike, and K. Satoh. 2000. Reduction of $Q_{A}$ in the dark: Another cause of fluorescence Fo increases by high temperatures in higher plants. Photosyn. Res. 63:23-34.

Acknowledgments. The author is grateful for funding from the International Society of Arboriculture and the Stanley Smith (UK) Horticultural Trust.

\section{${ }^{1 *}$ R.A. Bartlett Tree Laboratory, Europe \\ ${ }^{2}$ Research Student \\ The University of Reading \\ 2 Early Gate \\ Whiteknights \\ Reading, RG6 6AU, U.K.}

${ }^{*}$ Corresponding author.

Résumé. Le but de cette recherche était de déterminer si les valeurs de fluorescence de chlorophylle, obtenues à partir de feuilles excisées de plantes ligneuses soumises à une déshydratation in vitro, donnaient un indicateur mesurable de la performance globale de la plante suite une sécheresse in situ. Le but était également de fournir une meilleure compréhension des altérations dans les propriétés photosynthétiques de la feuille entre les espèces. En se basant sur des réductions de l'efficience photochimique (mesurée par la fluorescence chlorophyllienne) de feuilles détachées de 30 espèces ligneuses in vitro 24 heures après leur déshydratation, les plantes ont été classées par ordre de tolérance. Cinq espèces identifiées comme tolérantes, moyennement tolérantes et sensibles à la sécheresse ont été soumises à 70 jours de sécheresse en serre.
En se basant sur les taux de mortalité au $70^{\mathrm{e}}$ jour de sécheresse, la tolérance à la sécheresse suivait le même classement que pour le test in vitro. De plus, les réductions dans les paramètres de fluorescence chlorophyllienne et dans les taux de photosynthèse reflétaient le classement de tolérance observé in vitro, c'est-à-dire que les taux diminuaient plus rapidement pour les espèces identifiées comme facilement déshydratables et moins pour les espèces tolérantes à la sécheresse. L'altération des paramètres de fluorescence chlorophyllienne foliaire auprès des espèces testées a mis en lumière un certain nombre d'effets autrefois non reportés sur le mécanisme photosynthétique des feuilles en réponse à la sécheresse. Les résultats indiquent fortement que l'examen de matériel foliaire prélevé in vitro, au moyen de la fluorescence chlorophyllienne, peut fournir une bonne idée du taux de tolérance à la sécheresse des plantes, et ce avec une expérimentation limitée de la plante entière.

Zusammenfassung. Die Absicht dieser Studie bestand darin, zu bestimmen, ob die Werte an Chlorophyllfluoreszenz, die aus dehydrierten Blättern von Gehölzen in vitro gewonnen wurden, einen nachmessbaren Indikator für die Leistung einer ganzen Pflanzen nach einer Trockenperiode in situ liefern würden und daraus ein größeres Verständnis für Schwankungen in der Photosyntheseleistung zwischen den Arten resultieren könnte. Basierend auf Reduktionen der Photosyntheseleistung, wie sie durch die Chlorophyllfluoreszenz bei den geworbenen Blättern von 30 holzigen Pflanzen $24 \mathrm{~h}$ nach einer Dehydration in vitro gemessen wurde, ergab sich bei den Pflanzen entsprechend ihrer Toleranz eine Reihenfolge. Fünf Arten, die als trockenheitstolerant, -akzeptabel und -sensitiv eingestuft wurden, wurden 70 Tage unter Gewächshausbedingungen der Trockenheit ausgesetzt. Basierend auf der Sterberate nach 70 Tagen Trockenheit, blieb die Toleranz ähnlich wie die gewonnenen in vitro-Ergebnisse. Zusätzlich spiegelte die Reduktion der Fluoreszenzparameter und Photosyntheseraten der ganzen Pflanzen die Toleranzreihenfolge, d.h. die Raten sanken rapide bei den als sensitiv identifizierten Pflanzen und deutlich schwächer bei den trockenheitstoleranten Arten. Die Veränderung der Blattchlorophyllfluoreszenz in den getesteten Arten hob eine Reihe von vorher nicht berichteten Auswirkungen auf den Blattphotosyntheseapparat in Reaktion auf die Trockenheit hervor. Die Ergebnisse zeigen deutlich, dass das Untersuchen von geworbenem Blattmaterial in vitro trotz minimaler Experimentierungserfahrung an ganzen Pflanzen eine Grundlage bieten kann für das Messen von Trockenheitstoleranz. 
Resumen. El propósito de esta investigación fue determinar si los valores de clorofila fluorescente obtenidos de hojas de plantas leñosas sujetas a deshidratación in vitro, proporcionaron un indicador mensurable del comportamiento de la planta, posteriormente a la sequía in situ, y con ello obtener un entendimiento de las alteraciones en las propiedades fotosintéticas de la hoja entre especies. Los anterior, con base en las reducciones en la eficiencia fotosintética, medida por la fluorescencia de la clorofila, de las hojas de 30 plantas leñosas después de 24 horas deshidratadas in vitro. Las plantas fueron clasificadas en orden de tolerancia. Cinco especies identificadas como tolerantes, intermedias y sensibles a la sequía, estuvieron sujetas a 70 días de sequía bajo condiciones de invernadero. Con base en las tasas diarias de mortalidad en los 70 días de tolerancia a la sequía siguieron el mismo orden que los obtenidos in vitro. Además, las reducciones en los parámetros de la fluorescencia de clorofila y las tasas fotosintéticas de las plantas reflejaron que las de tolerancia in vitro declinaron más rápidamente que en las especies identificadas como sensibles a la deshidratación y menor en especies identificadas como tolerantes a la sequía. La alteración de los parámetros de la fluorescencia de clorofila en las especies probadas enseñó un número de efectos previamente no reportados en el aparato fotosintético en respuesta a la sequía. Los resultados indican que el escaneo del material foliar in vitro, utilizando fluorescencia de clorofila, pueden proporcionar una manera de conocer la tolerancia de las plantas a la sequía, con limitada experimentación. 